\section{Dorothy Canfield Fisher - Karen Blixens amerikanske forbindelse}

\author{
Aflektor Allan Røder
}

$\mathrm{F}$ orfatteren Dorothy Canfield Fisher er i dag så godt som ukendt herhjemme. Man vil kunne finde hende omtalt i nyere publikationer i vores nordiske nabolande, men i Danmark har hun ikke nydt en tilsvarende bevågenhed det sidste halve århundrede ${ }^{(1)}$. Og dog kan man hævde, at denne amerikanske forfatters betydning for litteraturen har været større i Danmark end i de fleste andre lande i Europa. For uden hende havde vi måske aldrig hørt om Karen Blixen eller hendes debutbog, Syv fantastiske Fortallinger. Dorothy Canfield sørgede i 1932 for, at fortællingerne fik den håndsrækning, der skulle til for at blive udgivet. Og takket være den bogklub, som hun arbejdede for, kunne hun medvirke til, at de kom ekstra godt fra start.

\section{Forfatter med indflydelse}

På det tidspunkt, hvor Canfield fik muligheden for at hjælpe, var hun 53 år, godt seks år ældre end Karen Blixen, og havde et omfattende forfatterskab bag sig, - otte romaner, deriblandt flere bestsellere, og en lang række noveller, - der afspejlede forfatterens drøm om et mere humant samfund præget af tolerance, ligeberettigelse og medmenneskelighed, og stilmæssigt førte traditionen videre fra det nittende århundredes realisme, ofte med et anstrøg af lokalkolorit fra hendes hjemstat Vermont.
De fleste af Canfields historier foregik i samtidens Amerika og handlede om gennemsnitlige middelklassemennesker, der prøvede at finde ud af at klare sig i hverdagen, finde ud af, hvad de ville, som kæmpede med problemer, gennemgik kriser, lærte noget nyt og til sidst - som regel - kom frem til en form for løsning og endte som mere modne eller selvsikre individer.

Hun skrev i stor udstrækning om og for kvinder, viste tidligt sin interesse for kvindesagen og vakte nogen opsigt, da hun i 1920'erne udgav en roman, hvor mand og kone byttede roller til alles bedste: han fik lov at blive hjemmegående, hvad han også helst ville, og hun fik endelig mulighed for at bruge sine evner som leder inden for det private erhvervsliv ${ }^{(2)}$; dette var en model, som Canfield også kendte lidt til fra sit eget liv, hvor hendes mand gennem alle årene tog sig af hus og have, mens hun selv passede sin karriere. Også i den eneste af Canfields bøger, der er udkommet på dansk, slog hun til lyd for at frigøre mødre fra deres bundethed i hjemmet, få dem ud på arbejdsmarkedet og ,bringe alle Kvinder til at tage et Arbejde op, der stemmer overens med deres naturlige Anlæg" (3).

Alt, hvad hun skrev, blev

værdsat af en stor læserkreds, både i og uden for hendes eget land, og hun blev af Eleanor Roosevelt karakteriseret som en af de ti kvinder, der i deres samtid havde den største indflydelse på andre amerikanske kvinders liv ${ }^{(4)}$. Der kan næppe herske tvivl om, at Canfield ønskede at bruge denne indflydelse i næsten alt, hvad hun skrev - uanset om det drejede sig om romaner eller skrifter om pædagogik eller betydningen af voksenundervisning, - til at påvirke folk i gunstig retning: få læserne til at erkende skævheder eller uretfærdigheder i samfundet, men også få dem til at vende blikket indad, erkende 


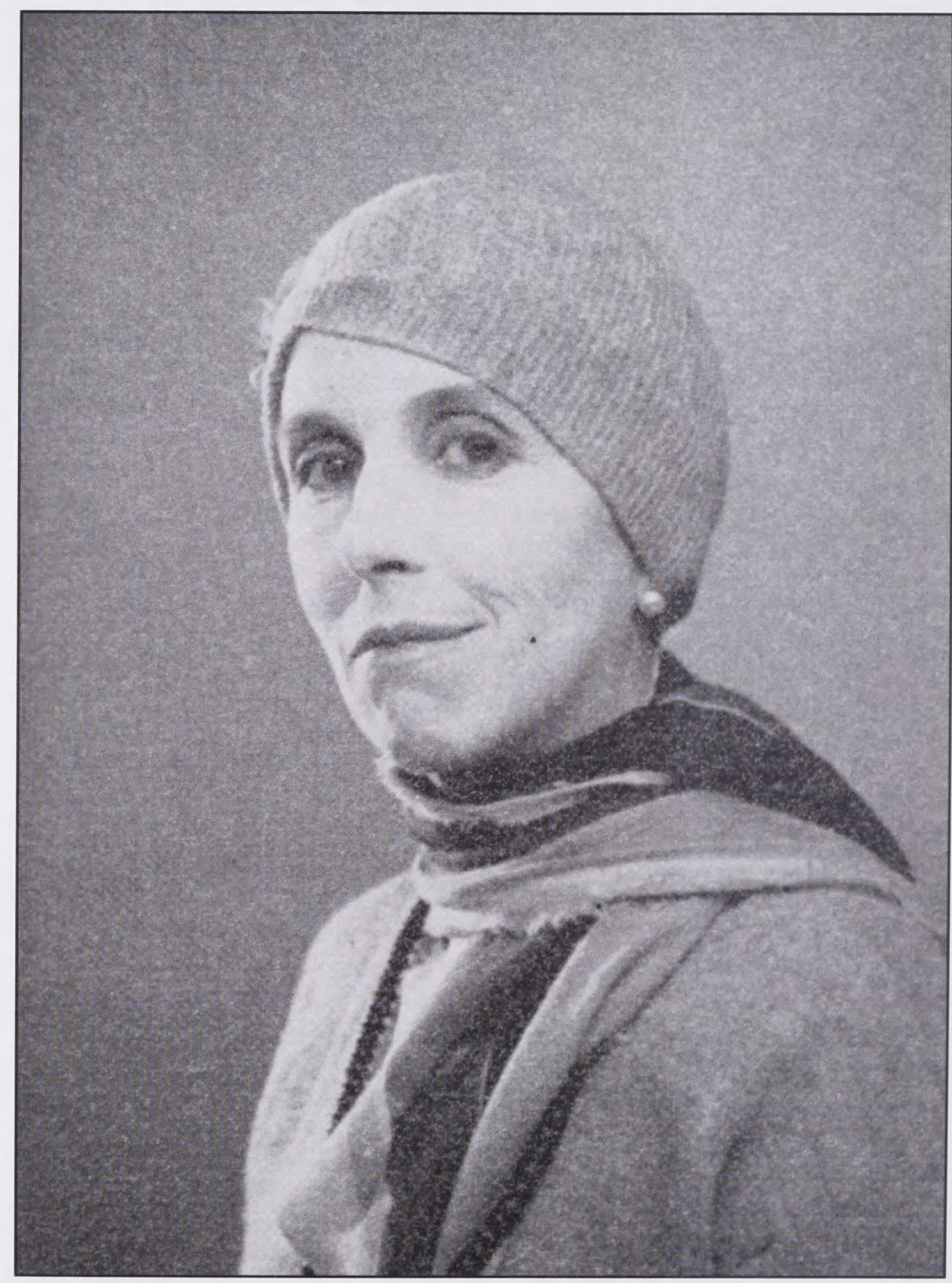

Karen Blixen (1885-1962), fotograferet i 1934. Samme ar udkom forfatterens bog Seven Gothic Tales $i$ USA under pseudonymet Isak Dinesen. (Foto: Kehlet) 
egne menneskelige fejl og svagheder og søge at rette op på dem.

Også i udvælgelseskomiteen på USAs dengang største bogklub, Book-ofthe-Month Club, fik hun lejlighed til at gøre sin indflydelse gældende, - en indflydelse, som efter nogles mening var betragtelig ${ }^{(5)}$. Her fik hun mulighed for at støtte de forfattere, som faldt $i$ hendes smag, og som hun mente mange læsere burde lære nærmere at kende, - og for at protestere mod dem, som ikke sagde hende noget. Mænd som Hemingway, Faulkner, Scott Fitzgerald og O’Neill hørte ikke til blandt hendes favoritter. Og ved den generationskløft, der i mellemkrigstiden dannede sig mellem de mere 'traditionelle' amerikanske forfattere på den ene side og de unge ikonoklaster på den anden, blev hun af mange betragtet som hørende til den førstnævnte gruppe.

I sin samtid kunne hun gøre sin indflydelse gældende, men hun havde ikke altid fingeren på pulsen. Hun havde ikke noget forhold til størstedelen af avantgarden og befandt sig i det store hele bedre i det stille Vermont end i Greenwich Village. Og mens hun var meget interesseret $\mathrm{i}$ at støtte kvindelige forfattere og etniske minoriteter, stod hun fremmed over for mange af de mere ekstreme naturalistiske og eksperimenterende tendenser, der nok kunne sætte deres præg på en del af den nye litteratur, men ikke på de udvalg, som bogklubben sendte ud til sine læsere. Mange af de forfattere, som hun foretrak, havde et eller andet sted - ved siden af eventuelle eksperimenterende islæt - bevaret en tydelig tilknytning til verden af $i$ går. Blandt sine samtidige havde hun en forkærlighed for f.eks. Willa Cather og Robert Frost, som også hørte til hendes private vennekreds.

\section{Book-of-the-Month Club}

Oprindelsen til Book-of-the-Month Club, som skulle komme til at spille en ikke ubetydelig rolle for Karen Blixen, - kan findes helt tilbage i 1916, da en ung reklamemand ved navn Harry Scherman af en ven blev præsenteret for en miniatureudgave af Shakespeares Romeo and Juliet, der var lille nok til at ligge i en vestelomme. Scherman kontaktede straks et firma, der solgte konfekture, og foreslog, at firmaet købte et parti af miniaturebøgerne og lagde dem ned i deres chokoladeæsker for at profilere sig. Konfektureproducenterne gik med på ideen. Snart blev ikke bare Romeo and Juliet, men også Hamlet og mange andre udødelige værker anbragt i chokoladeæskerne, og det blev en succes ${ }^{(6)}$.

Allerede samme år dannede Scherman og nogle af hans venner deres eget firma, „The Little Leather Library

Corporation ", og gjorde sig uafhængige af konfekturekoncernen. Oplaget steg gevaldigt, omsætningen voksede, og det samme gjorde udvalget, der snart også omfattede Platon og Dante og mange andre. De første år gik det strygende. Men efter 40.000 .000 miniatureklassikere var markedet meget tæt på at være mættet ${ }^{(7)}$. Scherman og hans partnere kunne nu se, at det ikke kunne holde, og prøvede at komme ud af det og sælge, men uden held. Indtil Robert K. Haas kom forbi.

I 1924 investerede Haas i firmaet og erhvervede den afgørende indflydelse. Han var uddannet på Yale, havde gjort karriere i bankverdenen og havde altid $ø$ nsket sig at blive bogudgiver. Men han var tilsyneladende ikke klar over, hvor dårligt det stod til med hans nye firma, der allerede måtte lukke året efter ${ }^{(8)}$.

Scherman fik dog snart den pengestærke Haas til at investere i et nyt 
projekt: The Book-of-the-Month Club. Haas indskød halvdelen af de 40.000 dollars, der var brug for, mens Scherman og en af hans venner skaffede den anden halvdel i fællesskab ${ }^{(9)}$.

Tanken med Book-of-theMonth Club var, at klubben hver måned skulle udvælge den bedste, nye bog, der var udkommet, og sende den ud til klubbens medlemmer. På den måde kunne folk hele tiden følge med i det bedste af den allernyeste litteratur uden at skulle bruge tid og energi på at opspore en boghandel eller et bibliotek, der jo ofte kunne ligge langt borte fra, hvor de boede, og uden selv at skulle igennem en masse litteratur for at finde frem til det, der virkelig var noget værd.

Problemet var, hvordan man overbeviste klubbens medlemmer om, at de bøger, de fik udsendt, virkelig var månedens bedste. Hér havde man brug for en eller anden faglig autoritet, der kunne indestå for bøgernes kvalitet. Man blev enige om at sammensætte en udvælgelseskomité, der kunne tage sig af denne del af sagen. De folk, der skulle sidde i komiteen, måtte være velkendte skikkelser, som folk vidste havde forstand på litteratur, men som stadig havde en solid jordforbindelse og en bred opbakning i forskellige dele af befolkningen. Man endte med en komité på fire mænd og én kvinde: Henry Seidel Canby, William Allen White, Christopher Morley, Heywood Broun og Dorothy Canfield. De var alle anerkendte skribenter, som på den anden side ikke virkede så intellektuelle og virkelighedsfjerne, at det ville skræmme folk væk ${ }^{(10)}$.

Det var de fem, der nogle år senere skulle tage stilling til Karen Blixens noveller.

Den, der havde mest at sige $\mathrm{i}$ komiteen, var Henry Canby. Han var professor i engelsk ved Yale og redaktør af The Saturday Review of Literature. På de højere læreanstalter havde han måttet beskæftige sig en del med tidligere tiders klassikere, men nu var han optaget af at finde en moderne litteratur, der tog fat på aktuelle, almindelige problemer og kunne sige folk noget i deres dagligdag. Han var ligesom resten af komiteen - ingen tilhænger af den naturalistiske avantgarde, som han fandt ofte var lovlig kynisk og uden nogen positive værdier, som læsere kunne holde sig til. Hans personlige favoritter var forfattere som Edith Wharton, Willa Cather og John Galsworthy ${ }^{(11)}$. Også Dorothy Canfield Fisher faldt i hans smag, og da han også var en af hendes bekendte, var han højst sandsynligt den, der pegede på Canfield og fik hende med i komiteen.

De øvrige fire medlemmer af Canbys panel havde hver især i forvejen deres tilhængere og faste læserskare. William Allen White var forfatter og redaktør fra Kansas og blev anset for at have stor appel til den almindelige gennemsnits-amerikaner, journalisten Heywood Broun fra New York stod i sine artikler på den tid som en slags talerør for storbymennesket, og Christopher Morley havde gennem sine underholdende, elegante romaner fået et godt tag i den del af læserskaren, der dengang gik for at være 'sophisticated'.

Canfields læsere var for størstedelens vedkommende kvinder, - specielt fra New England, men over hele landet var der kvinder, som læste hendes bøger og ville have tillid til hendes dømmekraft. Og også folk fra landsbyer og de små bysamfund kunne føle, at de i hende havde en pålidelig delegeret. Canfield boede selv gennem alle årene i en landsby - Arlington, Vermont - og var blevet kendt som en slags repræsentant for de små samfund, fordi hun gennem 
mange år i sine romaner og noveller havde forsvaret landsbylivet. Og alt tyder på, at netop kvinder og folk fra de små bysamfund udgjorde en væsentlig del af den nye bogklubs medlemmer ${ }^{(12)}$.

Tre af panelets fem medlemmer Canby, Canfield og Morley - havde en livsopfattelse, der var præget af kvækernes trosretning, og de møder, hvor de fem dommere skulle udvælge den næste bookof-the-month, foregik også efter kvækerprincippet, hvor alle skulle være enige, før der blev taget en beslutning. Det var meget demokratisk, men i årenes løb kunne det ikke undgås, at flere oplagte værker ikke blev valgt, fordi der blandt de fem medlemmer sad én, der ikke kunne udstå netop den forfatter. På den måde gik det f.eks. til, at Steinbecks Vredens druer blev forkastet - til hele panelets ærgrelse senere hen ${ }^{(13)}$.

For at hjælpe udvælgelseskomiteen blev der sideløbende oprettet en europæisk komité, bestående af bl.a. Thomas Mann, Sigrid Undset, H. G. Wells og André Maurois. Dette panel, der fungerede indtil 1939, skulle gøre amerikanerne opmærksomme på europæiske udgivelser, der kunne være af interesse for læserskaren i USA ${ }^{(14)}$.

Da The Book-of-the-Month Club officielt begyndte sin virksomhed i 1926, var det den første bogklub af sin art i den engelsktalende verden. Valget af den første bog - Lolly Willowes af Sylvia Townsend Warner - signalerede, at komiteen havde en vis smag for en 'fantasy' fortællestil, der havde fællestræk med Karen Blixens i Syv fantastiske Fortallinger ${ }^{(15)}$. Romanen blev sendt ud i april, og Scherman og hans partnere var mere end usikre på, hvordan det ville gå. Men efter det første år så alt ud til at gå, som det skulle. Af de ni titler, der i 1926 blev udvalgt til 'månedens bog', er det vel kun to, der i dag kendes af en større læserskare: John Galsworthys The Silver Spoon (en del af Forsyte-sagaen), og Edna Ferbers Show Boat, der senere blev omarbejdet til musical. Men hovedsagen var, at det gik fremad med medlemstallet, som i 1927 nåede op over 60.000 , - bl.a. takket være en salgsteknik, hvor det krævede en aktiv indsats at melde sig ud af klubben, hvis man først var blevet medlem ${ }^{(16)}$.

\section{Mary Westenholz}

Det var også i 1927, at Canfields venskab med Mary Westenholz, Karen Blixens tante, tog sin begyndelse. Det blev til en brevveksling, der skulle vare til frøken Westenholz' død tyve år senere. I al den tid var de to kvinder kun sammen i nogle få timer i alt, men i brevene, hvoraf mange er blevet bevaret, finder man ikke desto mindre ofte en meget varm og fortrolig tone.

$$
\text { Canfield var normalt ingen }
$$

tilhænger af overklasse eller aristokrater, og i hendes historier skildres folk med aristokratiske tendenser ofte som utiltalende ${ }^{(17)}$. Men disse følelser var ikke altid gengældt, og en engelsk viscount må tilskrives en del af æren for, at Canfield og Westenholz kom i forbindelse med hinanden. Edward Grey bidrog med sin ros til at gøre Canfield populær på denne side af Atlanterhavet; Westenholz hørte under en rejse i Skotland om udtalelserne, og da Grey med sin status som adelsmand og tidligere udenrigsminister virkede på Westenholz som én, hvis dom man måtte kunne regne med, satte hun sig snart til at læse Canfields nyeste roman - Her Son's Wife. Romanen gjorde et stort indtryk på hende. Hun skrev så til forfatteren, fik et venligt svar, og skrev snart efter tilbage. Den dansk-amerikanske forbindelse var derefter en realitet ${ }^{(18)}$.

Romanen handlede om en midaldrende kvinde, Mary Bascomb, og 


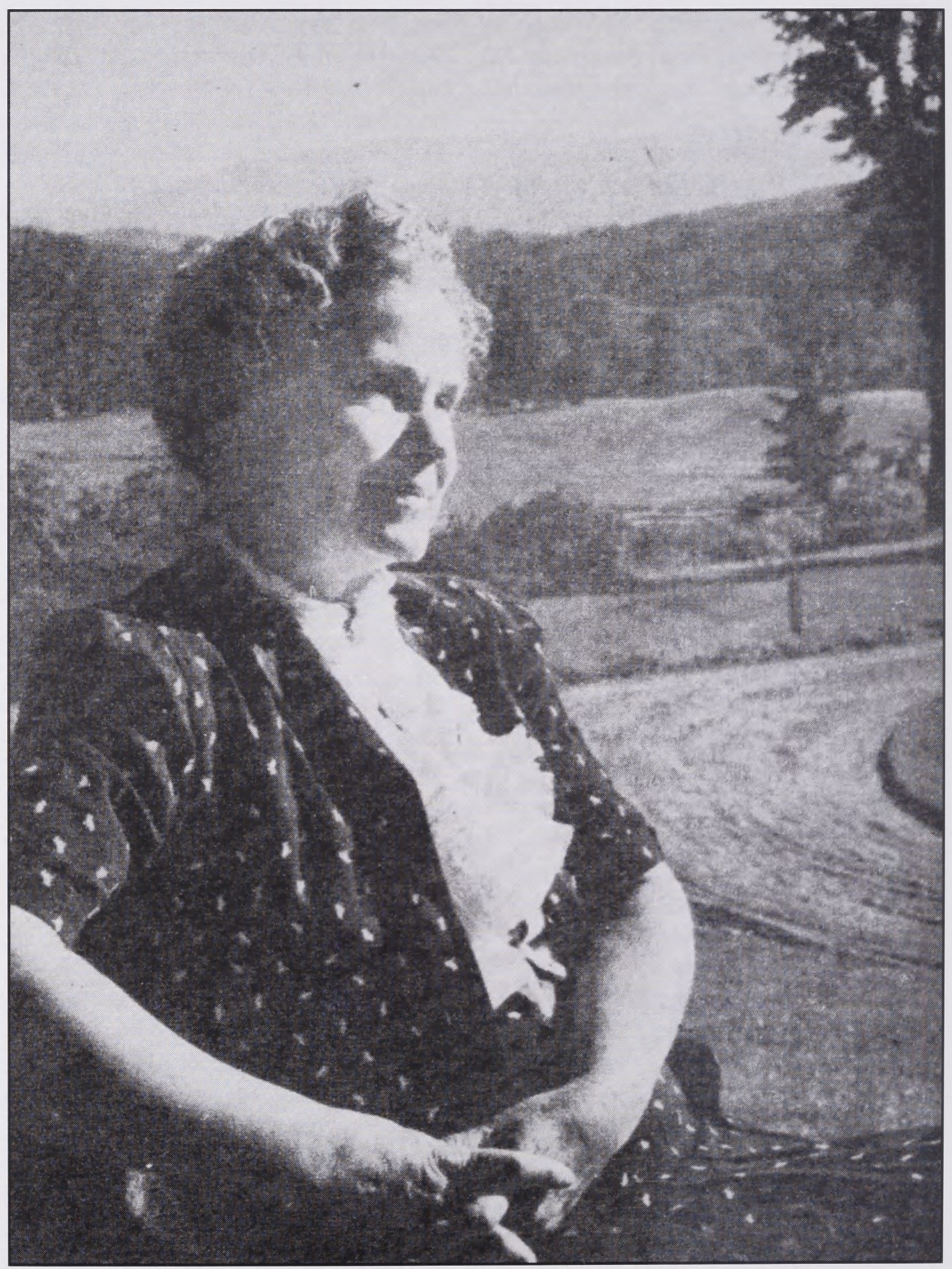

Forfatterinden Dorothy Canfield Fisher (1879-1958), der formidlede Karen Blixens kontakt med den amerikanske forlagger Robert K. Haas. Fotografi fra ca. 1950. 
hendes opgør med den yngre generation i familien. Mary er en enlig, selvstændig og myndig dame, som forfægter de kristne idealer og holder af forfattere som H. C. Andersen og Selma Lagerlöf ${ }^{(19)}$. Canfields hovedperson fremtræder som noget dogmatisk og moralsk til at begynde med, men rummer alligevel mange sympatiske træk, der viser sig efterhånden. I løbet af historien lærer Mary at lægge en dæmper på sig selv og får netop derved en positiv indflydelse på de unges liv, der har været præget af tankeløshed og umodenhed.

På det tidspunkt, da Mary Westenholz læste romanen, var hun lige fyldt 70 og inde i lidt af en krise. Hun var nedtrykt i perioder og tænkte meget over, om hun havde truffet de rigtige valg $i$ sit liv. Hun følte, at hun stod på den ene side af en generationskløft i sin familie, at hun med sine moralske, religiøse holdninger var kommet til kort over for de unge - især niecen Karen Blixen, hvis følelser over for den kristne tænkemåde ofte kunne virke ret kølige, og som kunne finde på at betegne sig selv som Lucifers barn ${ }^{(20)}$. I denne periode med usikkerhed og tvivl fandt Westenholz i Canfields roman en historie, som hun syntes fortalte hende noget væsentligt. Hun syntes, at hun nogle gange genkendte noget af sin egen situation i bogen, og hun var enig $i$ mange af Canfields holdninger. I sine breve vendte Mary Westenholz flere gange tilbage til, hvilken betydning netop den bog havde for hende.

En lang række breve gik herefter over Atlanten. Westenholz fik snart indblik i, hvordan livet så ud set fra staten Vermont, og Canfield fik udvidet sit kendskab til danske forhold meget betydeligt. Hun kunne ganske vist læse dansk til husbehov, fordi hun i sin ungdom havde læst H. C. Andersen på originalsproget og hele sit liv var en fan af ham ${ }^{(21)}$, men hendes hovedinteresse i Europa havde indtil nu altid været Frankrig, hvor hun havde gået i skole og studeret og lavet nødhjælpsarbejde under krigen. Begge kvinder kunne konstatere, at deres baggrund var meget forskellig, men at de ikke desto mindre på mange punkter lignede hinanden, - de interesserede sig begge for ligeberettigelse og samfundsanliggender, de var enige i flere af deres etiske grundholdninger, de værdsatte egenskaber som ansvarsfølelse over for andre, altruisme, det 'selvforglemmende', som Westenholz kaldte det ${ }^{(22)}$.

Venskabet blev grundfrstet, og

Westenholz benyttede sig snart af de muligheder, hun havde som en af lederne af det unitariske trossamfund i Danmark og tidligere redaktør af Protestantisk Tidende for at introducere Canfield for en større kreds. I 1928 gav hun sit nye bekendtskab den varmeste anbefaling, Canfield nogen sinde ville få på dansk jord: ,Jeg kender ingen nulevende Forfatter, der trænger dybere ind i Menneskers Sind, Hjerte, Natur og mere ligefrem og tilforladeligt, forstaaende, beundrende og overbærende fortæller, hvad hun der ser. Humor, Sundhed, Menneskekærlighed præger alt, hvad hun skriver, og hun skriver som Kunstneren af Guds Naade“(23).

Herefter fulgte et uddrag af en af Canfields noveller; Westenholz havde her flere tekster at vælge imellem, for den amerikanske veninde var allerede begyndt at sende hende sine udgivelser fra alle årene. „The First Time After" handlede om en soldat, der var blevet blind i krigen, var blevet hjemsendt, og nu måtte prøve at affinde sig med sit handikap. Historien understregede noget, som både Canfield og Westenholz troede på: betydningen af ikke at give op, også selv om man står over for 


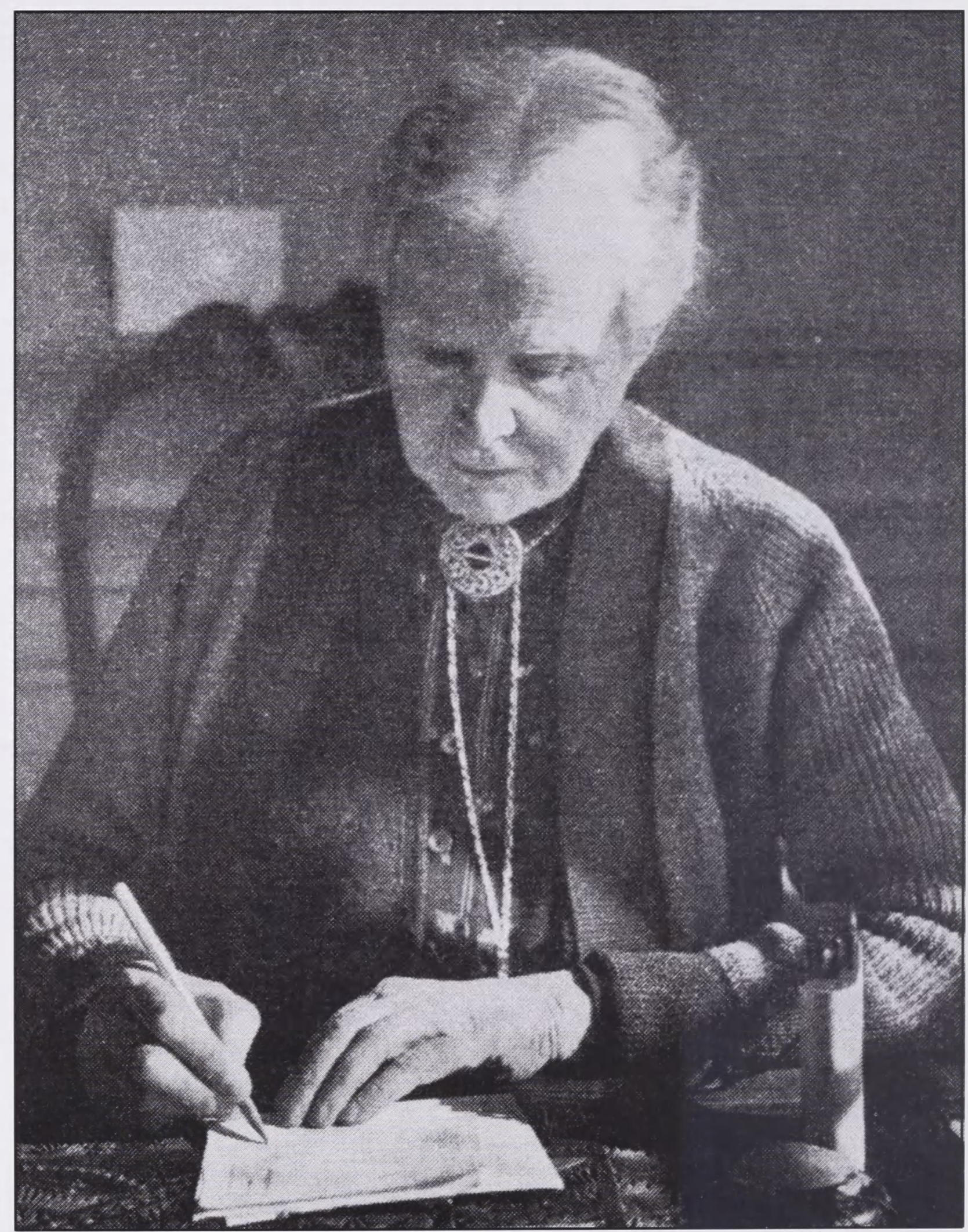

Venskabet mellem Mary Bess Westenholz (1857-1947) og Dorothy Canfield Fisher blev indledt $i$ 1927. Det blev til en brevveksling, der varede til Westenholz' dod tyve är senere. De to kvinder modtes kun kortvarigt ved en enkelt lejlighed i forbindelse med Canfields rejse gennem Europa hvor forfatterinden i sommeren 1930 aflagde et besøg hos Westenholz på Folehave. 
store problemer.

Under en rejse gennem Europa aflagde Canfield i sommeren 1930 et besøg hos Westenholz på Folehave, hvor hun ud over sin veninde mødte Karen Blixens bror og svigerinde Thomas og Jonna Dinesen, mens Karen Blixen selv stadig var i Afrika ${ }^{(24)}$. Besøget blev meget kort, da hovedformålet med turen egentlig var at besøge Canfields søn, som da opholdt sig på en skole i Sydtyskland; men de to kvinder nåede da at få talt sammen, og venskabet blev bekræftet.

\section{Karen Blixens debut}

1931 var et vigtigt år på begge sider af Atlanten.

For Book-of-the-Month Club var det året, hvor Canfield måtte slås for at få resten af komiteen til at se kvaliteterne i Pearl Bucks The Good Earth, som i første omgang var blevet forbigået ${ }^{(25)}$. At få komiteen bag sig betød et gennembrud for Pearl Buck, der et par år senere fik nobelprisen. Det var også i 1931, at Canfield blev optaget i The National Institute of Arts and Letters, og hvor Haas valgte at trække sig ud af bogklubben, som han mente havde sin bedste tid bag sig. Året efter grundlagde han forlaget Harrison Smith \& Robert Haas (der i 1936 blev lagt sammen med Random House) ${ }^{(26)}$, men opretholdt en tæt kontakt til bogklubben og specielt til Canfield, som efter hans mening var den bedste af udvælgelseskomiteens fem medlemmer ${ }^{(27)}$.

For Karen Blixen var 1931 året, hvor hun måtte opgive $\sin$ farm og rejse hjem til Danmark. Og dermed begyndte hendes indsats for at finde en forlægger. Allerede inden afrejsen fra Afrika havde hun sat sig i forbindelse med Christopher Morley - fra Book-of-the-Month Club -, som var en bekendt til en af hendes naboer og venner i
Afrika, Gustav Mohr. Men det havde ikke givet resultat ${ }^{(28)}$.

I sommeren 1932 fik Canfield brev fra Karen Blixens bror, Thomas Dinesen, som hun havde mødt under sit korte besøg i Danmark. I brevet blev Canfield bedt om at finde en udgiver til Blixens noveller, som var vedlagt ${ }^{(29)}$.

Novellerne gjorde indtryk på Canfield, og hun prøvede at finde ud af, om de havde nogen muligheder i den amerikanske forlagsverden. Samme sommer viste hun dem til en række forlæggere og litteraturinteresserede bekendte, - men med undtagelse af en enkelt Harvard-professor var ingen tilsyneladende i stand til at se kvaliteterne i dem, og mange af kommentarerne var endda temmelig nedslående ${ }^{(30)}$. Senere viste hun dem til en ven, forlæggeren Haas, som på trods af at flere af hans nærmeste medarbejdere på forlaget straks faldt for historiernes nye og anderledes kvalitet - $\mathrm{i}$ første omgang ikke ville forpligte sig ${ }^{(31)}$. Firmaet Harrison Smith and Robert Haas blev først grundlagt samme år, og det ville være risikabelt at begynde med at udgive noveller af en ukendt, europæisk forfatter midt i en stor, økonomisk depression.

Canfield mente dog ikke, at slaget dermed var tabt. Hun havde bl.a. forlæggeren Alfred A. Knopf i tankerne og sendte i december 1932 novellerne til sin litterære agent Reynolds, der undersøgte mulighederne for at få dem udgivet. Dette forsøg førte ikke til noget og blev opgivet først i det nye år. I april måtte Canfield meddele Karen Blixen, at forsøgene ikke hidtil havde båret frugt ${ }^{(32)}$. Dette fik imidlertid ikke den danske forfatter til at opgive; og ikke længe efter blev hun og Haas alligevel enige om en aftale, der så blev underskrevet 23. juni. I juli underrettede Blixen Canfield om den uventede succes ${ }^{(33)}$. 
Om Haas ombestemte sig på grund af overtalelse fra Canfields side eller på grund af Hervey Allens roman Anthony Adverse (Book-of-the-Month Clubs vældige succes fra 1933, der med sine italienske aristokrater, hestevogne, dueller og galante eventyr på visse punkter kan minde om „Vejene omkring Pisa“), er endnu uvist ${ }^{(34)}$.

Men under alle omstændigheder gjorde Harrison Smith \& Robert Haas nu alt klar til udgivelsen. Det blev overdraget Canfield at fortælle det amerikanske publikum om den nye og ukendte forfatter i et forord. Hun gav danskeren sin varmeste anbefaling og understregede, at det her drejede sig om historier, der var noget helt nyt og anderledes; noget, der måske kunne minde om R. L. Stevenson eller Hoffmann, men var noget helt for sig selv. Og Canfield følte da utvivlsomt også, at stilen i den nye bog var meget forskellig fra hendes egen og fra den, der var fremherskende i USA på det tidspunkt. Samtidig blev Karen Blixens ønske om anonymitet imødekommet, og Canfield søgte at skabe lidt mystik omkring forfatterens identitet: ,all that we are told is that the author is a Continental European, writing in English although that is not native to his pen, who wishes his-or-her identity not to be known" (35).

I 1934 skulle Seven Gothic Tales af Isak Dinesen så udkomme. Bogklubbens økonomisk set værste år nogen sinde - 1932 - var kun lige overstået, men det var begyndt at se lysere ud, og i udvælgelseskomiteen valgte man efter anbefaling fra Canfield og Morley at satse på Karen Blixen og udnævne danskerens debutbog til 'book of the month'. Det hjalp på salget, - og på den danske forfatters trængte økonomi. $\mathrm{Og}$ bogen blev vel modtaget. Efter Haas' skøn betød kåringen, at der blev solgt godt 17.000 ekstra eksemplarer i de amerikanske butikker ${ }^{(36)}$. Det varede herefter ikke længe, før medierne kom på sporet af, hvem der gemte sig bag forfatterpseudonymet, og den danske baronesse blev nu på kort tid kendt $\mathrm{i}$ store dele af verden.

Bogklubben skulle ikke komme til at fortryde sit valg; Seven Gothic Tales fremhæves gerne i beretninger om klubbens historie som en af de store succeser gennem tiderne ved siden af værker som Native Son af Richard Wright, Orwells Animal Farm, John Irvings The World According to Garp og Margaret Mitchells Gone With the Wind ${ }^{(37)}$. Og komiteen fortsatte gennem årene med altid at tage Blixens nye udgivelser med i betragtning. Da hun et par år senere udgav Out of Africa, blev også den valgt af bogklubben.

\section{Senere værker}

I mellemtiden fortsatte den transatlantiske brevveksling, og venskabet mellem de to kvinder, Canfield og Westenholz, blev yderligere styrket med årene. Canfield dedicerede sin næste novellesamling, Fables for Parents, „To dear Mary Westenholz“. Selv om Westenholz ikke kendte forældrerollen ud fra egen erfaring, mente Canfield alligevel, at samlingen kunne vække genklang på Folehave.

For det første var der i bogen $\mathrm{i}$ forbindelse med gentagne hentydninger til problemer mellem generationerne en tendens til en mere indfølende og forstående skildring af de fornuftige ældre mennesker end af det yngre slægtled; og de unge, som ikke vil tage imod fornuft, kommer let til at betale en pris for det, - som den unge kunstner i „An Unprejudiced Mind“, der kaster alle de ældres leveregler over bord - og ender med at gå til grunde.

For det andet var den ene af historierne skrevet på en måde, så den 


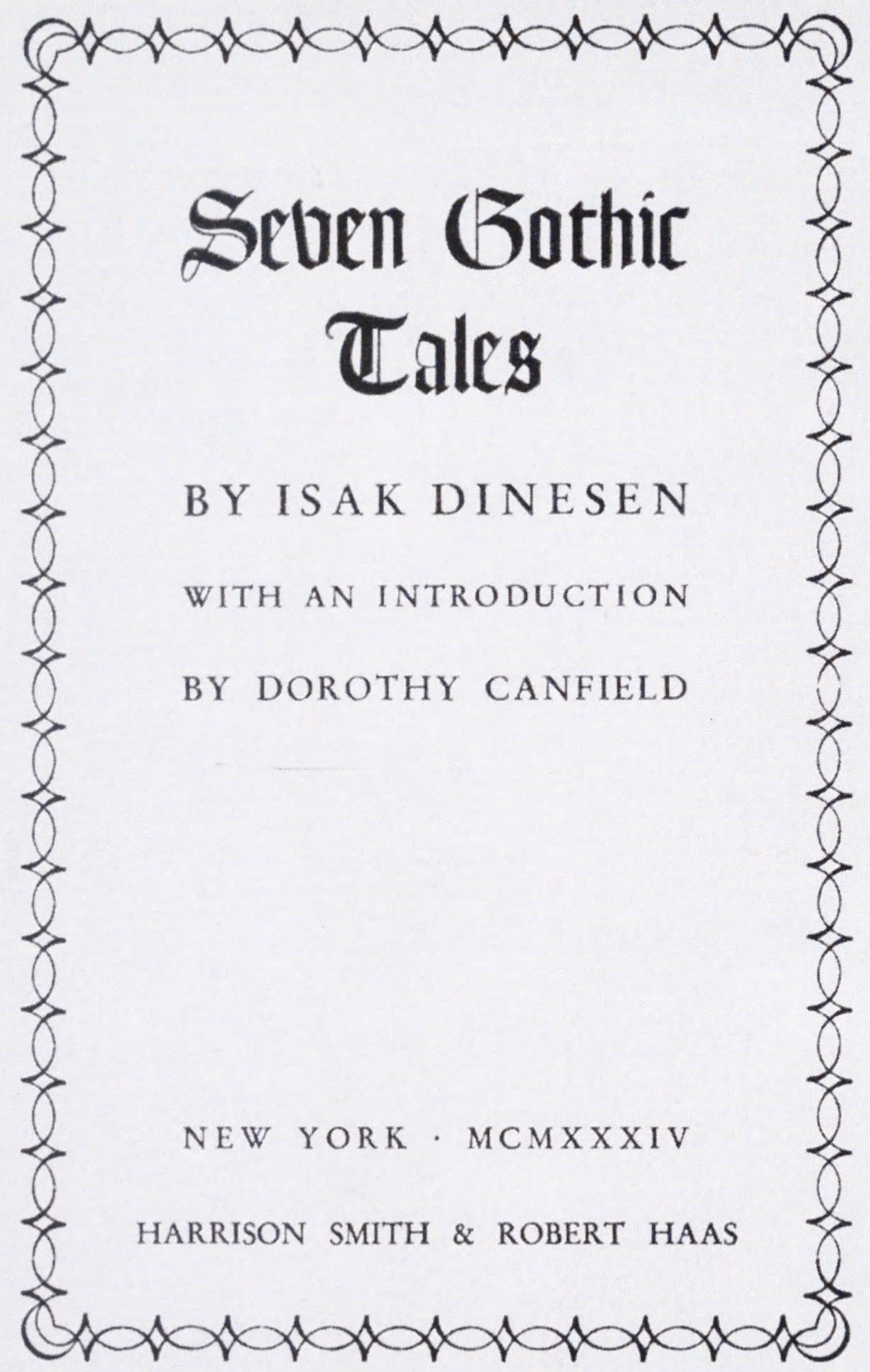

Da Seven Gothic Tales udkom i 1934 i USA blev Karen Blixens debutbog udnavnt til 'book of the month'. Det skonnedes at kairingen betod et ekstra salg på godt 17.000 eksemplarer. 
næsten var nødt til at sige Mary Westenholz noget. Canfield vidste, at Westenholz' yndlingsbog var og blev Her Son's Wife, ikke mindst pga. hovedpersonen, Mary Bascomb. I historien „Babushka Farnham“ skabte Canfield nu en kvinde, der lignede Mary Bascomb meget, - igen en enlig, kristen, respekteret og handlekraftig kvinde, noget oppe i årene uden at være gammel; men mindre dogmatisk og mere umiddelbart sympatisk end sin forgænger - og ligesom Westenholz - nært beslægtet med en ung kvindelig og meget talentfuld europæisk kunstner. Historien handlede nu om, hvordan den unge og den ældre kvinde efter først at have stået hinanden ret fjernt kunne finde sammen på tværs af generationskløften og hjælpe hinanden med at få hverdagen til at fungere.

Canfields sidste roman udkom i

1939. Den var et indædt angreb på nazisme og racisme, men handlede også om så småt at blive gammel og affinde sig med en mere tilbagetrukket rolle og finde glæde ved at følge med $i$, hvordan en ny generation kommer til verden og begynder livet.

Så brød krigen ud, og forbindelsen til Danmark blev snart afbrudt. Et par år senere skrev Canfield i et lidt vemodigt notat om Mary Westenholz: „She read some of my novels, began to write me, and our correspondence became one of the most comforting and enlightening elements of my life. She was (I assume, writing in 1944 , before any news from Denmark has come in, that she can hardly be alive now) much older than I“ (38).

Krigen fortsatte. Blixen lagde sidste hånd på Vinter-Eventyr og udtænkte handlingen til Gengaldelsens Veje, der i 1944 udkom under pseudonymet Pierre Andrézel. Canfield fortsatte med sit arbejde i udvælgelseskomiteen. En af de mere spændende opgaver i de år gik ud på et samarbejde med Richard Wright om nogle af de bøger, der i dag er klassikere - Native Son og Black Boy. Hun havde i årtier arbejdet for sortes ligeberettigelse og var glad for en lejlighed til at kunne gøre en konkret indsats for en lovende forfatter ${ }^{(39)}$. Derudover brugte hun meget tid på nødhjælpsarbejde, der berørte mange egne af verden og efter krigen medførte påskønnelser mange steder fra (bl.a. 'Kong Christian den Tiendes Frihedsmedaille'), og arbejdede på novellen "Sex Education“", der skulle blive en af hendes bedste, - om en kvinde, som gradvis når til en dybere forståelse af, hvad der egentlig skete, da hun som ung gjorde sine første seksuelle erfaringer. Den blev senere oversat til dansk og under den mere forsigtige overskrift „Tema med variationer" trykt $i$ et dansk ugeblad ${ }^{(40)}$.

Krigsafslutningen førte til genoptagelse af kontakten over Atlanten og til udveksling af flere gode nyheder. Canfield fik til sin meget store glæde besked om, at Westenholz stadig var ved nogenlunde godt helbred, - hun havde hørt, at Karen Blixens tante var død under krigen. Og Blixen fik fra Haas brev om, at hendes bøger, inklusive Winter's Tales, havde klaret sig godt i USA i de mellemliggende år og havde ført til betydelige indtægter ${ }^{(41)}$.

Men Gengaldelsens Veje skulle oversættes til engelsk; denne oversættelse var meget tæt på at skabe en krise i det danskamerikanske forhold og har formodentlig medvirket til, at Blixen til en vis grad ændrede syn på Canfield og bogklubben. Blixen mente ikke selv, at Gengaldelsens Veje havde nogen videre litterær værdi; hun havde ikke skrevet den for at skabe et stort kunstværk, men nærmest som underholdning for sig selv. Derfor var hun ikke tilfreds med, at den amerikanske bogklub ville vælge 


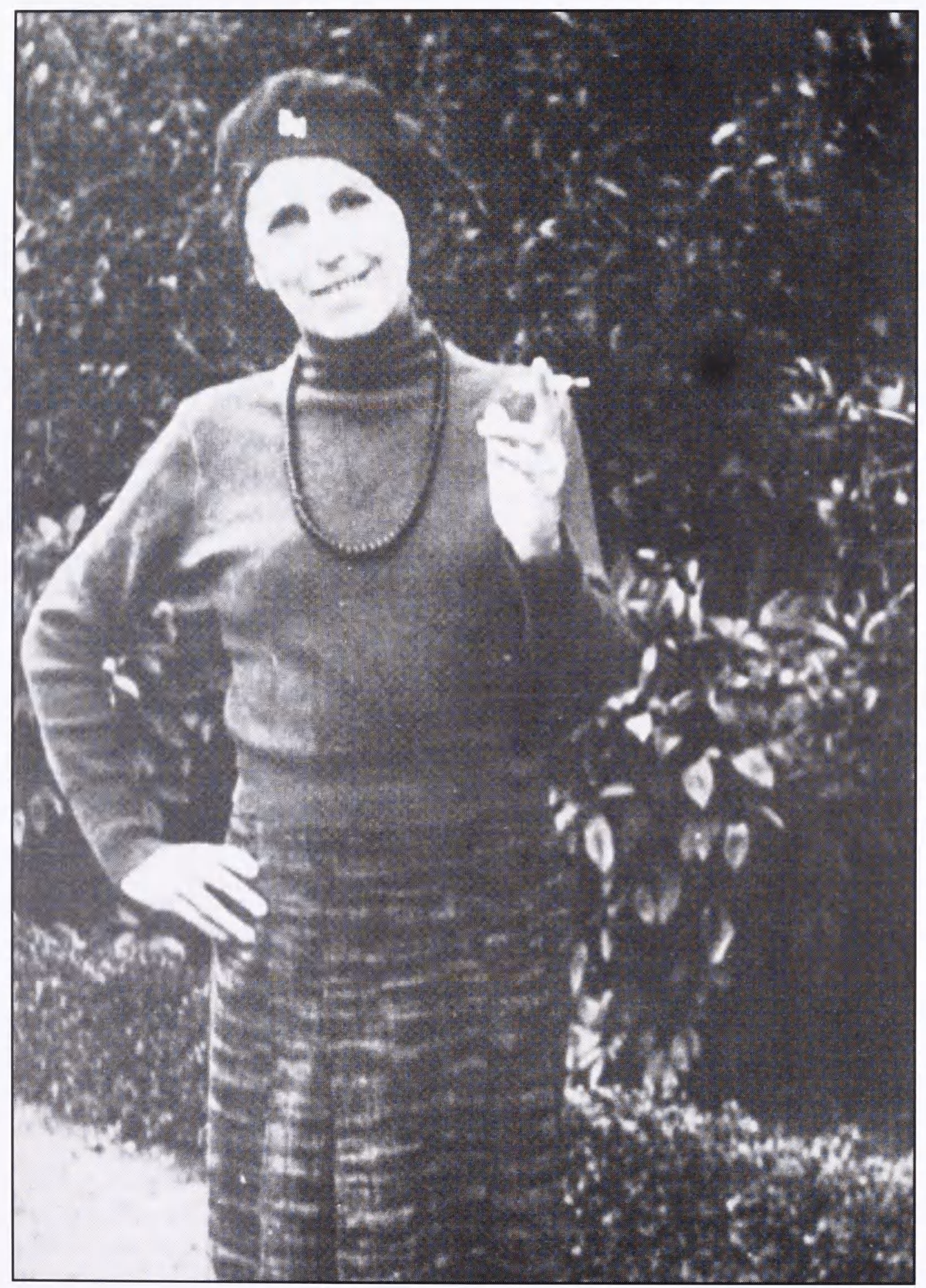

Efter forfatterens identitet var afsloret blev dette amatorbillede af Karen Blixen brugt som pressefoto $i$ England. 
hendes nye værk til månedens bog. Og at værket yderligere loyalt fik ros af Canfield, der ligesom flere af den tids litterater havde valgt at tolke handlingen allegorisk, affødte en undren hos Blixen. Hun nøjedes dog med at give udtryk for sin undren i de private cirkler og koncentrerede sig i den amerikanske korrespondance om at protestere mod klubbens udnævnelse; disse protester førte dog ikke til noget. The Angelic Avengers endte som 'book-of-the-month' ligesom hendes tidligere bøger ${ }^{(42)}$.

\section{De sidste år}

Mary Westenholz døde i 1947 efter lange perioder præget af dårligt helbred, tiltagende døvhed og nedtrykthed. Thomas Dinesen overtog herefter korrespondancen efter sin tante, som han holdningsmæssigt på mange punkter mentes at ligne, og holdt forbindelsen med Canfield ved lige ${ }^{(43)}$. Nogle af de ting, som Dinesen lagde vægt på, var samhørighedsfølelsen med slægten og forfædrene, nødvendigheden af at prøve at gøre de kommende generationer til moralsk ansvarlige mennesker, og mulighederne for et godt $\mathrm{og}$ fredeligt samfund i fremtiden; $\mathrm{og}$ det var emner, som også optog Canfield, og hvor hun i høj grad kunne følge ham ${ }^{(44)}$. Der udviklede sig efterhånden et varmt og venskabeligt forhold mellem den danske og den amerikanske forfatter, og gennem årene sendte de hinanden deres bøger, manuskripter og udkast. Snart havde Thomas Dinesen og hans hustru Jonna 12-14 af Canfields bøger stående, bøger, som også Karen Blixen læste $\mathrm{i}^{(45)}$.

En af Canfields tidlige noveller, „The Sick Physician “, har måske gjort et særligt indtryk på Blixen sidst i 1940'erne, hvor hun skrev „Babette's Feast“ til det amerikanske månedsmagasin Ladies' Home Journal, og givet hende nogle ideer til
Babettes og Philippas historie ${ }^{(46)}$.

Canfields novelle handler om Lisa, en kunstner, som for nylig er kommet til USA fra Europa og er helt på bar bund efter på tragisk vis at have mistet sin mand og sit eksistensgrundlag, men bliver hjulpet i gang igen af en gruppe amerikanske middelklassedamer.

Damerne, som lever i en temmelig triviel hverdag uden interesse for ret meget andet end husgerning og godgørenhed, tager sig af den gådefulde, nødstedte fremmede som en kristen forpligtelse og prøver først at hjælpe hende til at blive hushjælp og oplære hende i dagligdags husgerning.

Men det viser sig lidt efter lidt, at Lisa har meget større evner, end damerne har kunnet forestille sig; at den fremmede udlænding, dengang hun boede i Europa, var sangerinde, at hun er en stor kunstner. Hendes nye venner får nu helt nye perspektiver ind i deres liv, men selv kan hun på trods af de ekstatiske, religiøst betonede musikalske oplevelser, som hun giver dem, stadig ikke komme ud over sine personlige problemer.

Hendes sangtalent opdages af amerikanerne, da en mand fra operaen en søndag tilfældigvis er i byen og hører hende. Herefter går forberedelserne i gang til en titelrolle i operaen. Men netop som vejen til en stor karriere ligger åben, får hendes personlige forhold hende til at opgive det hele.

\section{Canfield fokuserede i sin novelle} på forholdet mellem liv og kunst og fik fremhævet, at kunst trods alt har sine begrænsninger, og at selv store kunstnere på langt de fleste punkter ikke er spor anderledes end andre mennesker; hvilket minder om det synspunkt, hun udtrykker andetsteds, at der ikke er noget ophøjet ved 
kunstnere, at de er ganske almindelige mennesker, som bare har en vældig, ubændig trang til at udtrykke sig og delagtiggøre andre i oplevelser ${ }^{(47)}$.

Men hvis man læser Lisas historie i dag, er det svært ikke at komme til at tænke på „Babettes Gæstebud“, - hvor den franske gastronom ender med at sætte store kunstnere i en klasse helt for sig selv, - de „har faaet noget, hvorom I andre slet intet ved“ (48).

I 1951 trak Canfield sig tilbage fra Book-of-the-Month Club. Gennem sine 25 år i bogklubben havde hun hver måned læst og bedømt op til 20 nye bøger, og nu var hendes syn begyndt at svigte. Hun blev afløst af en yngre dame, Amy Loveman, der allerede i mange år havde arbejdet inden for organisationen og som redaktør på Canbys Saturday Review of Literature ${ }^{(49)}$.

Karen Blixen tog i de år flere tilløb til besøg i USA, men aflyste igen på grund af sit dårlige helbred. Andre fra den danske familie kom på besøg hos Canfield i 1950 'erne, men at arrangere et møde mellem de to forfatterinder skulle vise sig at blive vanskeligt. I 1954 var det meget tæt på at lykkes: Thomas og Jonna Dinesen havde planer om et besøg i Arlington, Vermont, og Karen Blixen skrev til Canfield, at hun gerne ville med dem. Men nogen tid senere aflyste hun, og hendes bror og svigerinde kom til Arlington alene ${ }^{(50)}$.

Medvirkende til det positive forhold mellem den danske og den amerikanske familie var, at de to parter havde et positivt indtryk af hinandens hjemlande. Karen Blixen syntes godt om USA, hvor hun havde fundet sit første, store publikum. Og Canfield var til det sidste en beundrer af den danske samfundsmodel og kunne ikke forstå, at nogen - som Blixens far, Boganis, i sin tid - kunne blive træt af ,the Danish way of life, predictable, reasonable, self-controlled, about which so many American authors have written admiringly" "(51).

Men selv om de respekterede hinandens lande, blev det personlige forhold mellem de to forfattere aldrig til et venskab, der tilnærmelsesvis kunne sammenlignes med det meget varme og fortrolige forhold, som Canfield havde haft til Mary Westenholz, eller bare til den venskabelighed, der prægede forholdet til Thomas Dinesen. Canfield fortalte i breve til Karen Blixen om sin beundring for hende, men omtalte hende ikke altid rosende over for andre ${ }^{(52)}$. Blixen gav over for Canfield udtryk for sin store taknemmelighed for hjælpen i sin tid, men lod privat skinne igennem, at hun ikke var nogen beundrer af sin amerikanske kollega og nævnte hende normalt ikke offentligt ${ }^{(53)}$.

I 1958 udkom en bog, der omhandlede Canfields liv. Hun var ikke tilfreds med den; den virkede på flere punkter naiv og forenklet og gjorde meget lidt ud af de værker, hun havde skrevet ${ }^{(54)}$. Denne biografi gik hende meget på og fremskyndede sandsynligvis et sammenbrud. Hun døde i november samme år. Hun nåede derfor aldrig at møde Karen Blixen, der for første gang i sit liv kom til USA få måneder senere og i januar 1959 holdt tale $\mathrm{i}$ National Institute of Arts and Letters. Book-of-the-Month Club fortsatte sit arbejde med at gennemgå og vurdere nyudkomne bøger. Efter midten af 1950 'erne var der ikke nogen af de oprindelige fem udvælgelsesdommere tilbage ved de månedlige møder i New York, - Canby og Morley var de sidste, - men en ny generation stod parat til at overtage ${ }^{(55)}$, og de holdt fast ved Blixens forfatterskab til det sidste.

Shadows on the Grass var en af de bøger, der blev valgt i 1961, året før Karen Blixens død. 
I de sidste år har der været flere forandringer i bogklubben. 1980'erne var gennemgående præget af en vis tilbagegang i salgstallene, og det skabte uro omkring udvælgelseskomiteen, der endte med at blive afskaffet ${ }^{(56)}$. Dette affødte protester fra medlemmerne; og efter at Bookof-the-Month Club i marts 2000 blev en del af bogklubgiganten Bookspan med i alt mere end 9 millioner medlemmer, blev der i slutningen af 2001 indført et nyt panel, hvis opgave det nu er at tage arven op efter de oprindelige fem kommitterede og søge at finde frem til det mest læseværdige blandt hver måneds mange nye udgivelser ${ }^{(57)}$.

I vore dage er Stephen King en af de forfattere, der oftest har været tilbudt bogklubbens medlemmer, men man søger til stadighed at finde noget for enhver smag, og mange andre forfattere har haft glæde af organisationens opbakning. I Danmark blev det særligt bemærket, da månedens bog var Peter Høegs Frøken Smillas fornemmelse for sne.

Det er nu over fyrre år siden Dorothy Canfield Fishers død. I en længere periode derefter var der en tilbøjelighed til at glemme, hvad hun havde stået for. Men siden 1980 'erne er udviklingen vendt. Hvad hun gjorde og skrev, bliver atter trukket frem, hendes romaner og noveller bliver genudgivet, et udvalg af hendes breve er kommet på tryk ${ }^{(58)}$.

Samtidig bliver også den indflydelse, som hun havde på sin samtid gennem mange år i bøgernes verden, atter taget op til vurdering. Og også i Danmark er der grund til ikke at glemme hende helt.
Noter

1. Jf. f.eks. Nationalencyklopedin, bind 6 (Höganäs: Bra Böcker, 1991) og Aschehoug og Gyldendals store norske leksikon, bind 2

(Oslo: Kunnskapsforlaget, 1983). I

Danmark skal man tilbage til Den lille Salmonsen i 1930'erne, Hagerups samt Raunkjars leksika i 1940'erne for at finde hende i tilsvarende værker.

2. Dorothy Canfield: The Home-Maker (New York: Harcourt, Brace, 1924; Chicago: Academy Chicago, 1983).

3. Dorothy Canfield Fisher: En Montessori-Bog for Mødre (København: Pio, Branner, 1919), s. 172.

4. Elizabeth Yates: The Lady from Vermont. Dorothy Canfield Fisher's Life and World (Brattleboro: Stephen Greene Press, 1971), s. 249.

5. Janice A. Radway: A Feeling for Books. The Book-of-the-Month Club, Literary Taste, and Middle-Class Desire (Chapel Hill, London: University of North Carolina Press, 1997), s. 268.

6. Charles Lee: The Hidden Public. The Story of the Book-of-the-Month Club (Westport:

Greenwood Press, 1973), s. 21-22.

7. Al Silverman (udg.): The Book of the Month. Sixty Years of Books in American Life (Boston, Toronto: Little, Brown, 1986), s. xiii.

8. Charles Lee, s. 24-25.

9. Ibid., s. 30 .

10. Ibid., s. 35 .

11. Janice A. Radway, s. 177-178.

12. Charles Lee, s. 148-151.

13. Al Silverman, s. xvii-xviii, 94.

14. Charles Lee, s. 35-36.

15. Al Silverman, s. xiii-xiv. - Kirsten Røder: „Ingredienser til en bestseller. Om Karen Blixens Syv Fantastiske Fortællinger", kronik, Politiken, 3/10 1981, 2. sektion, s. 6.

16. Janice A. Radway, s. 187. - Charles Lee, s. 30,161 . 
17. Allan Røder: „Dorothy Canfield Fisher and the American Cultural Revolution“ (speciale, 1982), s. 25, 26.

18. Ida H. Washington: Dorothy Canfield Fisher. A Biography (Shelburne: New England Press, 1982), s. 79. - Brev fra Mary Westenholz til Canfield, 8/1 1928; Dorothy Canfield Fisher Collection, Bailey/Howe Library, University of Vermont (box 22, folder 11).

19. Dorothy Canfield: Her Son's Wife (London: Virago, 1986), s. 253. - Selma Lagerlöf var med sine kristne grundholdninger også en af Mary Westenholz' yndlinge.

20. Karen Blixen: Breve fra Afrika 1914-31 (København: Gyldendal, 1998), 1. del, s. 94-95; 2. del, s. 76, 124, 140-142.

21. Mark J. Madigan (udg.): Keeping Fires Night and Day. Selected Letters of Dorothy Canfield Fisher (Columbia, London: University of Missouri Press, 1993), s. 29.

22. Bertel Wrads: Fra mit Pulterkammer (København: Gyldendal, 1895), s. 36, 81.

23. Protestantisk Tidende, 1/5 1928, s. 105. Det er sandsynligvis denne artikel, som Canfield hentyder til, når hun i et brev til forlæggeren Alfred Harcourt skriver: "I've added a comment from a Danish magazine which somebody has just sent me. I like to be liked by the Scandinavians because I like them" (Mark J. Madigan, s. 134).

24. Om rejsen og besøget: Mark J. Madigan, s. 152, 176, 264 samt breve fra Mary Westenholz til Canfield, 25/11 1929, 20/ 11 1946; Dorothy Canfield Fisher Collection, Bailey/Howe Library, University of Vermont (box 22, folder 11).

25. Ida H. Washington, s. 200-201.

26. Mark J. Madigan, s. 344. - Charles Lee, s. 42.

27. Janice A. Radway, s. 281.

28. Frans Lasson og Tom Engelbrecht (udg.): Karen Blixen i Danmark. Breve 1931-62, bind 1 (København: Gyldendal, 1996), s. 148. - Karen Blixen: Breve fra Afrika 191431, 2. del, s. 224.
29. Hele denne brevveksling findes i Grethe Rostbøll: „Om 'Syv fantastiske Fortællinger'. Tilblivelsen, udgivelsen og modtagelsen af Karen Blixens første bog. En dokumentation", i Blixeniana 1980, red. af Hans Andersen og Frans Lasson (København: Karen Blixen Selskabet, 1980), s. 29264.

30. Til professor De Voto fra Harvard skrev Canfield tre år senere: „Do you remember my having with me, the summer of 1932 , some of the manuscript of what was later published as The Seven Gothic Tales [...]. I asked several people whose judgment I respect to help me decide whether I'd have a good chance of getting them published [...]. You were the only person who, at that time, liked them at all!" (Mark J. Madigan, s. 187)

31. Senere fortalte Canfield om Karen Blixens fortællinger: „Well, I tried them, tentatively, on several American publishers. I've never told this before; I think it's perhaps interesting as how such things go. They were always returned promptly". Først efter disse afslag, fortalte Canfield, præsenterede hun Haas for fortællingerne: „and I perfidiously did not tell him that I'd already tried them on several other publishers“ (Louis M. Starr: „An Interview with Dorothy Canfield Fisher", side 61. Columbia University Oral History Collection. 1956). Jf. den mere skånsomme version, som Canfield gav Thomas Dinesen i sit brev fra august '32: at forlæggeren Haas tilfældigvis netop var på besøg, da fortællingerne ankom, at Canfield tog fat på at læse det omfattende, tilsendte manuskript, mens han stadig var der, og at han derefter fik dem i hænde som den første læser i Amerika ud over Canfield selv.

32. Mark J. Madigan, s. 177-178.

33. Frans Lasson og Tom Engelbrecht, bind 1, s. $90,95,109$.

34. Grethe Rostbøll: „Om 'Syv fantastiske Fortællinger'“. Blixeniana 1980, s. 61. - 
Charles Lee, s. 166.

35. Isak Dinesen: Seven Gothic Tales (New York: Random House, Modern Library, 1934), s. vi. - Thomas Dinesen beskrev senere hele udgivelsesforløbet og Canfields indsats som mere ukompliceret: ,jeg sendte hende Tannes værk, og hun svarede mig næsten omgående: Fortællingerne er glimrende, jeg skal straks få min forlægger til at antage dem" (Thomas Dinesen: Tanne. Min søster Karen Blixen (København: Gyldendal, 2001), s. 125.

36. Charles Lee, s. 30, 207.

37. Al Silverman, s. xiv, xviii, 153.

38. Dorothy Canfield Fisher Collection, Bailey/Howe Library, University of Vermont (box 22, folder 11).

39. Mark J. Madigan, s. 18.

40. Novellen fremhæves som en af Canfields bedste i Dictionary of Literary Biography, bind 102 (Detroit, London: Gale Research Inc., 1991), s. 109. På dansk i Alt for damerne, 1/8 1950, s. 20-22, 29-30.

41. Mark J. Madigan, s. 254. - Frans Lasson og Tom Engelbrecht, bind 1, s. 427.

42. Frans Lasson og Tom Engelbrecht, bind 1, s. 440-441; bind 2, s. 525-526. - Judith Thurman: Isak Dinesen. The Life of a Storyteller (New York: St. Martin's Press, 1982), s. 340, 350.

43. Håndskriftssamlingen, Det Kongelige Bibliotek. Brevsamlingen: Dinesen, Westenholz.

44. Jf.: Thomas Dinesen: Øksen (København: Jespersen og Pio, 1959), s. 89, 99-101, 118. - Thomas Dinesen: Boganis. Min Fader, hans Slagt, hans Liv og hans Tid (København: Gyldendal, 2001), s. 9.

45. Meddelelse fra fru Jonna Dinesen, 1982.

46. "The Sick Physician“ er fra The Real Motive (New York: Henry Holt, 1916), s. 311-334. Angående novellens titel, jf. Lukas 4,23; Lisa er lægen, der ikke kan læge sig selv.

47. Dorothy Canfield: Raw Material (New York: Harcourt, Brace, 1923), s. 14: „The writer is not born (as is his boast) with more capacity than other people for seeing color and interest and meaning in life; he is born merely with an irrepressible desire to tell everybody what he sees and feels $[\ldots]$. This is the queer mainspring of creative literature. The writer cannot keep a shut mouth. To speak out seems to be the only useful thing he can do in life".

48. Karen Blixen: Skabne-Anekdoter (København: Gyldendal, 1998), „Babettes Gæstebud“, s. 73.

49. Charles Lee, s. 113, 223.

50. Frans Lasson og Tom Engelbrecht, bind 2, s. 219, 236. - Meddelelse fra fru Jonna Dinesen, 1982.

51. Dorothy Canfield Fisher: Vermont Tradition (Boston: Little, Brown, 1953), s. 285.

52. Ida H. Washington: „Isak Dinesen and Dorothy Canfield: The Importance of a Helping Hand“. Eunice Myers and G. Adamson (udg.): Continental, Latin and Francophone Women Writers, bind 1 (Lanham, New York, London: University Press of America, 1987), s. 94. - Mark J. Madigan, s. 307.

53. Frans Lasson og Tom Engelbrecht, bind 2, s. 236.

54. Elizabeth Yates: Pebble in a Pool (New York: E.P. Dutton \& Company, 1958). Genudgivet i 1971 som The Lady from Vermont.

55. Charles Lee, s. 223.

56. Doreen Carvajal: „Triumph of the Bottom Line", The New York Times, 1/4 1996, s. C 5. - Janice A. Radway, s. 354.

57. Se http://www.writenews.com/2001/ 062901_bom_panel.htm.

58. En kritisk gennemgang af den seneste Canfield-forskning findes i Annika LjungBaruth: A Steady Flameless Light. The Phenomenology of Realness in Dorothy Canfield Fisher's The Brimming Cup, Her Son's Wife and Rough-Hewn (Stockholm: Almqvist och Wiksell, 2002), s. 3-5. 